\title{
Microbiological Quality of Household Refrigerators in Three Cities South- West of Nigeria
}

Flora Oluwafemi $^{1 *}$, Sarah Akpoguma ${ }^{1}$, Taiwo Oladiran ${ }^{1}$ and Adelodun Kolapo ${ }^{2}$

${ }^{1}$ Department of Microbiology, Federal University of Agriculture, Abeokuta, Nigeria

${ }^{2}$ Department of Biology, The Polytechnic, Ibadan, Nigeria

\begin{abstract}
Household refrigerators are a potential source of pathogen contamination for foods leading to food spoilage and food borne diseases. This study was carried out to examine the consumers' knowledge and hygiene status of household refrigerators in Ibadan, Lagos and Abeokuta. One hundred and eighty households were randomly selected. Questionnaires covering social demographic characteristics, refrigerator quality and maintenance practices, householders' knowledge about food borne diseases, and frequency of electricity supply were administered. The interior of each refrigerator was swabbed using a sterile swab stick that had been pre-soaked in peptone diluent. Each sample collected was plated out on four different culture media viz. Nutrient agar, MacConkey agar, Mannitol Salt agar and Potato Dextrose agar. Results showed that majority of the householders had good knowledge of food borne disease, powered their refrigerators with generators and have some levels of education. Some refrigerators were completely free from contamination (neither bacteria nor fungi was detected) while others were found to be contaminated. Total viable count of bacteria ranged between 0 and $14.1 \times 10^{6} \mathrm{cfu} / \mathrm{ml}$ while fungi count ranged from 0 to $6.8 \times 10^{6} \mathrm{cfu} / \mathrm{ml}$. Bacteria and fungi isolated from the refrigerators were Staphylococcus aureus, Escherichia coli, Bacillus subtilis, Enterobacter spp., Klebsiella spp. and Shigella spp., Aspergillus flavus, A. niger, A. fumigatus, Saccharomyces cerevisae and Rhizopus spp. Findings show the presence of microorganisms which can cause food spoilage and food borne diseases. Educational programmes are needed to improve the refrigeration practices and the issue of regular supply of electricity is paramount in the hygiene of refrigerators.
\end{abstract}

Keywords: Household refrigerators; Knowledge about food safety; Demographics; Electricity; Microbial quality; Food spoilage; Food borne illness; Education; Nigeria

\section{Introduction}

Consumers store various kinds of food in refrigerator at an inappropriate temperature which could give rise to food borne diseases or illness [1]. Food borne pathogens are the leading cause of illness and death in less developed countries. In the developed countries food borne pathogens are responsible for millions of cases of infections such as gastrointestinal diseases each year [2]. New food borne pathogens and food borne diseases are likely to emerge due to factors such as pathogen evolution, changes in Agriculture and food manufacturing practices and changes in the human host status [3].

Refrigerators are one of the most important kitchen appliances found in homes used in storing and keeping food products so as to prolong the shelf-life of the foods. Refrigeration is employed to control the rate of certain chemical and enzymatic reactions as well as rate of growth of food microorganisms [4]. Lower temperature in a confined volume lowers the reproduction rate of bacteria, so the refrigerator reduces the rate of spoilage. Cooling is a popular food storage technique in many countries and works by decreasing the reproduction rate of bacteria. The device is thus used to reduce the rate of spoilage of foodstuffs [5].

Foods are stored in the refrigerators for preservation so as to be available for future use. Refrigeration is employed to control the rate of certain chemical and enzymatic reactions as well as rate of growth of food microorganisms [4]. When there is contamination with microbes, this can cause food spoilage (change in characteristics of food rendering it unacceptable or unsafe for consumption) and food borne diseases (defined by WHO, as any disease of an infectious or toxin nature caused by or thought to be caused by the consumption of food or water).
A study has shown that perishable food will deteriorate, even at refrigeration temperature, due to spoilage because of microorganisms, enzymes and oxidation [6]. Type of container or wrapping material they are stored in and duration of storage are also important factors that influence the type of microbial growth, toxicity and spoilage of food during refrigerated storage. Although low temperature retards spoilage but even a sub- freezing temperature of about $-7^{\circ} \mathrm{C}$ does not prevent multiplication of all microorganisms. Refrigerated foods are therefore subjected to spoilage by moulds, yeasts and bacteria [7].

The global incidence of food-borne disease is difficult to estimate, but it has been reported that in 2005 alone, 1.8 million people died from diarrhoeic diseases [8]. Inadequate food handling at processing sites is frequently implicated in outbreaks $[9,10]$. Consumers associate Food Borne Illness (FBI) with the consumption of foods outside of home; however, it is well known that foods prepared and consumed at home also represent a risk for FBI outbreaks [11-13]. Indeed, FBI originates in private homes three times more frequently than in food service operations [14]. Research indicates that perhaps as many as $50 \%$ of household FBI can be attributed to an inappropriate food storage including ineffective chill storage and refrigerator management [15]. Bacteria from unwashed raw foods, leaking packages, unclean hands, and unclean container surfaces introduced into domestic refrigerators

${ }^{*}$ Corresponding author: Flora Oluwafemi, Department of Microbiology, Federal University of Agriculture, Abeokuta, Nigeria, Tel: +2348035028602; E-mail: foluwafemi2000@yahoo.co.uk

Received May 28, 2015; Accepted June 30, 2015; Published July 08, 2015

Citation: Oluwafemi F, Akpoguma S, Oladiran T, Kolapo A (2015) Microbiological Quality of Household Refrigerators in Three Cities South-West of Nigeria. J Microb Biochem Technol 7: 4 206-209. doi:10.4172/1948-5948.1000206

Copyright: @ 2015 Oluwafemi F, et al. This is an open-access article distributed under the terms of the Creative Commons Attribution License, which permits unrestricted use, distribution, and reproduction in any medium, provided the original author and source are credited. 
can directly contaminate other stored foods and persist on internal refrigerator surfaces. This in turn creates the risk of indirect long-term contamination during subsequent food preparation [16].

It was reported that foodborne illnesses in the African region recorded a dramatic rise in 2008; anthrax in Zimbabwe; typhoid fever in Uganda,chemical poisoning due to consumption of seed beans and maize in Nigeria and Kenya; cholera from several countries e.g., Mozambique, Nigeria, Congo, Zambia, DRC, Kenya, Tanzania, South Africa, Zimbabwe; pesticide poisoning from cabbage and other vegetables in Senegal; fish mouse in Mauritius; mushroom poisoning in Algeria; Botulism and Hepatitis A in Uganda; Gala Night Dinner Meal, Nigeria [17].

Poor refrigeration has been reported to be a contributory factor to food borne illness. The most common problem in Nigeria is keeping foods in the danger zone of $4^{\circ} \mathrm{C}$ to $60^{\circ} \mathrm{C}$. This is due to the fact that electricity supply is erratic. The aims of this study are to examine the food safety knowledge of householders, determine the general hygiene status of different household refrigerators and the temperature status of domestic refrigerators in three cities south west of Nigeria.

\section{Materials and Methods}

\section{Study protocol (questionnaire distribution)}

In this study, the three cities selected are Ibadan, Sango-Ota and Lagos. In these selected cities, we focused on high density areas which were mainly inhabited by the middle and low income individuals. In each city, sixty households that were willing to participate in the study were randomly selected. The evaluation of householders' knowledge in relation to the use of refrigerator was done by giving questionnaires consisting of questions covering social demographics, refrigeration practices, refrigerator maintenance practices, incidence of food borne diseases etc. to each householder (owner of refrigerator) of the selected houses with plea to be sincere with their responses.

\section{Refrigeration temperature determination}

A thermometer was inserted into the refrigerator and removed after few minutes. The temperature was read and noted.

\section{Microbiological analysis of samples}

A total of 180 household refrigerators were sampled in Ibadan, Lagos and Abeokuta. With the consent of the householders the interior of each refrigerator was swabbed using a sterile swab stick that had been soaked in peptone diluents. The swab sticks were transported back to the laboratory under chilled conditions $\left(4^{\circ} \mathrm{C} \pm 1.0\right)$. Each sample collected was plated out on the following commercially available culture media in the laboratory after appropriate serial dilution was done:

Nutrient Agar for total mesophilic count

MacConkey Agar for Enterobacteriaceae count

Mannitol Salt Agar for Staphylococcus aureus count

Potato Dextrose Agar for fungal count

The bacteria plates were incubated at $37^{\circ} \mathrm{C}$ for 48 hours, and the fungi plates were incubated at room temperature $\left(28 \pm 2^{\circ} \mathrm{C}\right)$ for five days.

\section{Characterization and identification of bacterial isolates}

This was done according to standard methods described by Olutiola et al., [18]. The methods involved Gram staining, morphological, and cultural and biochemical characteristics

(Catalase, coagulase, oxidase, methyl red, Voges Proskauer, citrate reduction, indole and sugar fermentations test).

\section{Characterization and identification of fungal isolates}

Two drops of lactophenol blue was put on a clean glass slide containing mycelia growth. The mould isolates were examined macroscopically and microscopically using the schemes of Klich [19].

\section{Results}

Table 1 shows the social demographic, refrigerator maintenance practices and food safety knowledge of the householders that participated in the study. Educational statuses of respondents show that they all have some levels of education ranging from National Certificate of Education to Doctor of Philosophy.

Between $15 \%$ and $25 \%$ of households had 3 hours of light in the cities reported while 40 - 70\% had electricity for 6-9 hours and 5 - 20\% had electricity for 10-12 hours. Sango-Ota had no erratic electricity supply. No respondent reported all round electricity supply. It was seen that the different locations in the three cities had different electricity distribution patterns. Sango Ota had regular electricity supply than Ibadan and Lagos. This led to the issue of using generators to power their refrigerators. The time each respondent empowered his refrigerator with generator varies from individual to individual.

Another factor that could have affected the microbial quality of refrigerators was the cleaning regimes. Most respondents reported varying degrees of cleaning regimes. On weekly basis, $25-80 \%$ of respondents reported cleaning their refrigerators as shown in Table 1. Between $20 \%$ and $75 \%$ reported cleaning their refrigerators on monthly basis and no respondent reported yearly cleaning.

A key factor in determining the microbiological quality of refrigerators is the temperature regimes of the sampled refrigerators. Results show that 53 households had refrigerators whose temperatures were less than $5^{\circ} \mathrm{C}$, while 127 refrigerators had greater than $5^{\circ} \mathrm{C}$ (Table 2 ). The microbiological analysis of the refrigerators revealed various degrees of microbiological contamination. Out of the 180 refrigerators sampled microbiologically, 14 refrigerators had total viable bacterial counts of less than or equal to $10^{6} \mathrm{cfu} / \mathrm{ml}$ while 166 refrigerators had greater than or equal to $10^{6} \mathrm{cfu} / \mathrm{ml}$. S. aureus counts showed that 42 refrigerators had counts less than or equal to $10^{6} \mathrm{cfu} / \mathrm{ml}$ when compared with 138 refrigerators that had counts greater than or equal to $10^{6} \mathrm{cfu} /$ $\mathrm{ml}$. Thirty refrigerators had Enterobacteriaceae counts of less than or equal to $10^{6} \mathrm{cfu} / \mathrm{ml}$ while 150 refrigerators had counts greater than or equal to $10^{6} \mathrm{cfu} / \mathrm{ml}$. Fungal counts of 20 refrigerators were less than or equal to $10^{6}$ propagules while 160 refrigerators had above $10^{6}$ propagules $/ \mathrm{ml}$ (Table 3). Bacteria and fungi isolated include: Staphylococcus aureus, E. coli, Pseudomonas aeruginosa, Bacillus subtilis, Enterobacter sp., Penicillium sp., Saccharomyces cerevisae, Mucor, Aspergillus niger, A. fumigatus, Klebsiella sp.

\section{Discussion}

Consumers associate food borne illness with the consumption of foods outside of home; however, it is well known that foods prepared and consumed at home also represent a risk for Food Borne Illness (FBI) outbreaks [11-13]. Indeed, FBI originates in private homes three times more frequently than in food service operations [14]. Research indicates that perhaps as many as $50 \%$ of household FBI can be attributed to an inappropriate food storage including ineffective chill 


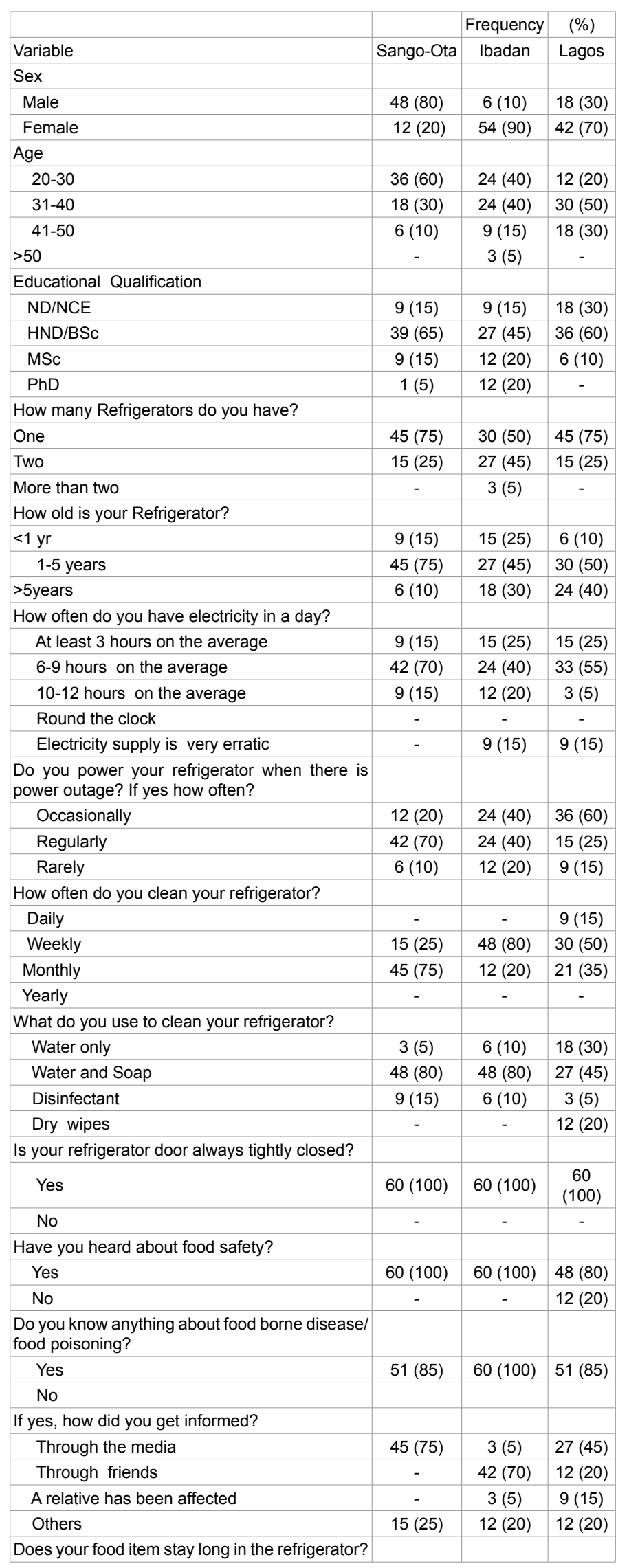

\begin{tabular}{|l|c|c|c|}
\hline Yes & $45(75)$ & $6(10)$ & $36(60)$ \\
\hline No & $15(25)$ & $54(90)$ & $24(40)$ \\
\hline How long do you store leftovers & & & \\
\hline Less than 24 hours & $18(30)$ & $39(65)$ & $21(35)$ \\
\hline 24 hours & $39(65)$ & $18(30)$ & $36(60)$ \\
\hline 1 week & $3(5)$ & $3(5)$ & $3(5)$ \\
\hline
\end{tabular}

Table 1: Social demographic, refrigerator maintenance practices and food safety knowledge of householders in three South-Western Nigerian cities.

storage and refrigerator management [15]. Bacteria from unwashed raw foods, leaking packages, unclean hands, and unclean container surfaces introduced into domestic refrigerators can directly contaminate other stored foods and persist on internal refrigerator surfaces. This in turn creates the risk of indirect long-term contamination during subsequent food preparation [16].

In this study it was seen in the questionnaires that most householders do not have steady electricity supply and this affected the temperature regimes of refrigerators (Table 2). Out of the 180 refrigerators sampled only $53(29.4 \%)$ had temperature of $\leq 4^{\circ} \mathrm{C}$. Most refrigerators are not functioning optimally due to power failure or erratic power supply, resulting change in the refrigerator temperature to greater than $4^{\circ} \mathrm{C}(70.6 \%)$ which will allow growth of mesophilic microorganisms which can be pathogenic and therefore increases the risk of food borne disease [20,21]. As important as electricity is to powering the refrigerator, none of the householders do have electricity round the clock. Some householders reported having 6-9 hours of electricity, others reported 3 hours daily while others do not have any defined pattern of electricity (erratic). These findings show that most refrigerators do not work optimally because temperature will change when there is no adequate supply of power to the refrigerators [22]. This may not be the case for some householders that get alternative source to power their refrigerators in some selected rich communities and some industrial areas especially are specially favored in the electricity distribution pattern like SangoOta. The total viable count contamination levels observed in this study show that 14 out of 180 refrigerators had bacteria count below a million colonies while 166 refrigerators had bacteria count above a million colonies (Table 3 ). The bacteria counts for S. aureus and coliforms shown in Table 3 were high. The levels of contamination observed in domestic refrigerators are likely to be influenced by a range of factors including the nature and levels of initial contamination introduced on contaminated foods, the presence and absence of effective packaging, the hygiene of those preparing and placing foods into the refrigerators, and the efficiency and frequency of refrigerator maintenance and cleaning [23].

The presence of microorganisms in the refrigerator affects the microbial quality of foods kept in it. During the course of this study and with the aid of the results from the questionnaires given for knowledge survey it was observed that irregular power supply, level of cleanliness and general knowledge of food safety greatly accounted for the presence of spoilage and pathogenic microorganisms inside the refrigerator.

This study identified the presence of undesirable food related pathogens such as Escherichia coli, Staphylococcus aureus, Bacillus subtilis, Pseudomonas spp., Aspergillus fumigatus, A. niger, Penicillium $s p p$. which were isolated from 170 refrigerators sampled.

S. aureus and E. coli were the most frequently isolated pathogen in this study and were recovered from $75 \%$ of the 170 refrigerators examined. Unlike the other microbial pathogens, which principally 


\begin{tabular}{|c|c|c|}
\hline Temperature & $\leq 4^{\circ} \mathrm{C}$ & $\geq 4^{\circ} \mathrm{C}$ \\
\hline Number of refrigerators & 53 & 127 \\
\hline
\end{tabular}

Table 2: Temperature regimes of 180 household refrigerators..

\begin{tabular}{|c|c|c|}
\hline Microorganisms & Frequency $\leq 10^{6}$ & $\geq 10^{6}$ \\
\hline Total Viable Count & 14 & 166 \\
\hline S. aureus Count & 42 & 138 \\
\hline Enterobacteriaceae Count & 30 & 150 \\
\hline Fungi Count & 20 & 160 \\
\hline
\end{tabular}

Table 3: Microbial counts obtained from swabbed surfaces of 180 household refrigerators

enter domestic kitchens from previously contaminated raw foods, S. aureus as a common inhabitant (up to 50\%) of the human nose, throat, and skin [24] is perhaps more likely to contaminate foods and refrigerators by direct or indirect human contact during domestic food handling and storage. As a gram-positive organism, it is relatively resistant to drying and is, therefore more likely to become dominant than more desiccation-sensitive organisms, especially in the low water activity conditions which prevail in domestic refrigerators.

E. coli is widely accepted indicator of fecal contamination suggesting that the refrigerator internal surfaces are frequently contaminated by import of contaminated raw foods or by poor personal hygiene. It is impossible to completely exclude food pathogens from the kitchens; however their spread, growth and survival can be controlled with correct food storage and preparation of practices and regular cleaning and disinfection of food contact site. E. coli, Klebsiella sp., Enterobacter spp. and Shigella spp. are enteric organisms that can cause gastroenteritis, Hemolytic Uremic Syndrome and shigellosis $[25,26]$.

The three Aspergillus spp. are agents isolated from household refrigerators that can cause food intoxication as they possess toxins which are harmful to the body when contaminated foods are consumed. Majorly A. flavus isolates produce mycotoxins such as aflatoxins. Aflatoxin B1 is known to cause toxic carcinogenic, mutagenic and teratogenic effect in patient. The International Agency for Research on Cancer (IARC) has designated aflatoxin as a human liver carcinogen.

This study has shown that food pathogens can survive on refrigerator surfaces and could therefore, pose a cross contamination risk. The need to have constant power supply and making sure the refrigerator is working at the normal chilling temperature is highly important to reduce the growth of these microorganisms. The potential risk of these organisms is heightened by their ability to multiply at refrigeration or mild abused temperatures. The recommended time in which, chilled foodstuffs are stored at required temperatures in case of power failure vary e.g. from 2 to 6 hours. The pathogens found in domestic refrigerators could contaminate food directly or indirectly and pose a major health risk to consumers in terms of food poisoning. Thus, food safety knowledge with a focus on kitchen hygiene and prevention of cross contamination is necessary if the scale and effect of domestic food borne illness is to be reduced. Storage (refrigeration), at appropriate temperature should be practiced.

\section{References}

1. American Chemistry Council (2010) Food Storage Safety Tips for the Fridge and Freezer.

2. Chan Z, Jiang $X(2004)$ Microbiological safety of chicken litter or chicken litterbased organic fertilizers: A review. Agric 4: 1-29.

3. Fratamico PM, Bayles DO (2005) Foodborne pathogens: Microbiology and Molecular Biology. Caister Academic Press.
4. Srivastava RP, Kumar S (2006) Fruit and Vegetable Preservation: Principles and Practices, (3rdedn), Lucknow: International Book Distributing Co. India.

5. Godwin S, Chen FC, Chambers E (2006) Correlation of visual perceptions of cleanliness and reported cleaning practices with measures of microbial contamination in home refrigerators. Food Prot Trends 26: 474-480.

6. Jay MJ (2000) Food Analysis: Theory and Practices, (3rdedn), CBS Publishers and Distributors, New Delhi.

7. Roday N (2002) Food Hygiene and Sanitation, Tata McGraw Hill Publishing Co. Ltd., New Delhi.

8. Hendriksen RS, Vieira AR, Karlsmose S, Lo Fo Wong DM, Jensen AB, et al (2011) Global monitoring of Salmonella serovar distribution from the World Health Organization Global Foodborne Infections Network Country Data Bank: Results of quality assured laboratories from 2001 to 2007. Foodborne Pathog Dis 8: 887-900.

9. Knight A, Worosz M, Lapinski M, Ten-Eyck T, Haris C, et al. (2005) Consumers perception of the food safety system: Implications for food safety educators and policy makers. Food Prot Trends 28: 391-406.

10. Scott E (2003) Food safety and foodborne disease in 21 st century homes. Can $\mathrm{J}$ Infect Dis 14: 277-280

11. Jackson V, Blair IS, McDowell D, Kennedy J, Bolton DJ (2007) The incidence of significant foodborne pathogens in domestic refrigerators. Food Cont18:346-351.

12. Nesbitt A, Majowicz S, Finley R, Marshall B, Pollari F, et al. (2009) High-risk food consumption and food safety practices in a Canadian community. J Food Prot 72: 2575-2586.

13. Redmond EC, Griffith CJ, Slader J, Humphrey TJ (2004) Microbiological and observational analysis of cross contamination risks during domestic food preparation. Brit Food J 106: 581-592.

14. Kennedy J, Jackson V, Blair IS, McDowell DA, Cowan C, et al. (2005) Food safety knowledge of consumers and the microbiological and temperature status of their refrigerators. J Food Prot 68: 1421-1430.

15. Godwin S, Chen FC, Chambers E, Coppings R (2007) A comprehensive evaluation of temperature within home refrigerators. Food Prot Trends 26: 474-480.

16. Michaels B, Ayers T, Celis M, Gangar V (2001) Inactivation of refrigerator biofilm bacteria for application in the food service environment. Food Service Technol 1:169-179.

17. World Health Organization (2012) Food safety and foodborne illness.

18. Olutiola PO, Famurewa O, Sonntag HG (2000) An introduction to General Microbiology: A practical approach. (2ndedn), Bolabay Publications, Ikeja.

19. Stephen W Peterson (2002) Identification of common Aspergillus species Central bureau voor schimmel cultures Netherlands by Klich MA. Mycologist 17: 128-128.

20. James SJ, Evans J, James C (2008) A review of the performance of domestic refrigerators. J Food Eng 87: 2-10.

21. Macias-Rodriguez ME, Hidalgo VN, Linares-Morales JR, Olea-Rodriguez MA Villaruel, et al. (2001) Inactivation of refrigerator biofilm bacteria for application in the food service environment. Food Service Technol 1:169-179.

22. Parry SM, Slader J, Humphrey T, Holmes B, Guildea Z, et al. (2005) A casecontrol study of domestic kitchen microbiology and sporadic Salmonella infection. Epidemiol Infect 133: 829-835.

23. Flynn OMJ, Blair I, McDowell D (2006) The efficiency and consumer operation of domestic refrigerators. Intl J Refrig 15: 307312.

24. Arbuthnott JP, Coleman DC, de Azavedo JS (1990) Staphylococcal toxins in human disease. Soc Appl Bacteriol Symp Ser 19: 101S-107S.

25. Williams KP, Gillespie JJ, Sobral BW, Nordberg EK, Snyder EE, et al. (2010) Phylogeny of gammaproteobacteria. J Bacteriol 192: 2305-2314.

26. Elliott EJ (2007) Acute gastroenteritis in children. BMJ 334: 35-40. 